\title{
An Alternative Chronology for the Xia Dynasty and Discussion on Issues Related to Xia Culture
}

\author{
Jia Hongbo 賈洪波 \\ Professor of History, Nankai University, China \\ wahbji@aliyun.com
}

Translated by Carl Gene Fordham

\begin{abstract}
This paper proposes an alternative chronology for the Xia dynasty [ca. 2100-1600 BCE] based on the respective year counts and generation numbers of the Xia, Shang [ca. 1600-1046 вСE], and Zhou [1046-256 BCE] dynasties. It argues that Qi 啟 founded the Xia dynasty midway through the twentieth century вС $\mathrm{E}$ and further discusses questions relating to the capital cities and culture of the Xia. By integrating archeological material, it further contends that the ancient city of Wangchenggang 王城崗 located in Dengfeng 登封 was Yangcheng 陽城, the capital established by Yu 禹. It also argues that the Wadian 瓦店 site in Yuzhou 禹州 may have been inhabited by Yu and Qi, that the ancient city of Xinzhai 新些 was an early capital of the Xia dynasty from the reigns of Qi to Shao Kang 少康, and that the Erlitou 二里頭 site was the capital of the Xia dynasty during its middle and late periods after the reign of Di Huai 帝槐. Xia culture should be approached as a concept that blends the disciplines of archeology and history and defined as the Xia people and the Xia dynasty within its region of governance or a culture whose creators mostly consisted of the Xia people. Furthermore, the ruins of the Xinzhai period represent Xia culture during its formative period, while Erlitou culture represents Xia culture during its maturity.
\end{abstract}

\section{Keywords}

capital city - chronology - Erlitou culture - Xia culture - Xia dynasty - Xinzhai period 
The increasingly optimistic period of Xia dynasty (ca. 2100-1600 BCE) research we now find ourselves in is foreshadowed by over half a century of archeological exploration. ${ }^{1}$ It is now generally accepted among academics that the Erlitou 二里頭 culture, or most of it, is Xia culture. ${ }^{2}$ However, disagreement remains on some specific issues, particularly as discoveries have come to light about important sites, such as Wangchenggang 王城崗, Wadian 瓦店, Huadizui 花地嘴, and Xinzhai 新砦, which have reignited discussion of Xia culture in its early period, a topic that remains divisive to this day. Xu Hong 許宏 [b. 1963] once stated that no research on the matter can be considered decisive without documentary evidence, and that no conclusion regarding Xia culture can be brushed aside. ${ }^{3}$ This paper attempts to surmise a Xia dynasty chronology with an alternate rationale.

1 This article is a translated and edited version of the original, published in Zhongyuan Wenwu 中原文物, vol. 5, 2017.

2 See Zhang Zhongpei 張忠培, “Guanyu Erlitou wenhua he Xiadai kaoguxue yicun de ji dian renshi 關於二里頭文化和夏代考古學遺存的幾點認識 [Some Interpretations of Erlitou Culture and Archeological Remains of the Xia Dynasty]," Zhongguo lishi wenwu 中國歷史文物, no. 1 (2009); Li Boqian 李伯謙, “Qianyan 前言 [Foreword],” in Zaoqi Xia wenhua yu xian Shang wenhua yanjiu lunwenji 早期夏文化與先商文化研究論文集 [A Collection of Essays on Early-PeriodXia Culture and Pre-Shang Culture Research], ed. Beijing daxue zhendan gudai wenming yanjiu zhongxin 北京大學震旦古代文明研究中心 [Peking University Zhendan Center for Ancient Civilizations Research] et al. (Beijing: Kexue chubanshe, 2012); Liu Xu 劉緒, “Dui tantao zaoqi Xia wenhua de ji dian kanfa 對探討早 期夏文化的幾點看法 [Some Views on Early-Period Xia Culture]," in Zaoqi Xia wenhua yu xian Shang wenhua yanjui lunwenji, 7-15; Chen Xu 陳旭, "Erlitou yiqi wenhua shi zaoqi Xia wenhua 二里頭一期文化是早期夏文化 [Phase I of Erlitou culture Is Xia Culture in Its Early Period]," in Zaoqi Xia wenhua yu xian Shang wenhua yanjui lunwenji, 16-25; Zhang Zhongpei, "Xu 序 [Foreword]" to Erlitou wenhua shiqi de Zhongguo 二里 頭文化時期的中國 [China during the Time of Erlitou Culture], by Duan Tianjing 段天 璟 (Beijing: Shehui kexue wenxian chubanshe, 2014); Xu Zhaofeng 徐昭峰 and Cao Rui 曹荵, “Kaoguxue yu Xia wenhua tansuo 考古學與夏文化探索 [Exploring Archeology and Xia Culture]," in Xia Shang duyi yu wenhua yi: Xia Shang duyi kaogu ji jinian yanshi shangcheng faxian 30 zhou nian guoji xueshu yantaohui lunwenji 夏商都邑與文化 (一): 夏商都邑考古暨紀念偃師商城發現 30 週年國際學術研討會論文集 [The Cities and Culture of the Xia and Shang Dynasties, vol. 1: Proceedings of the International Symposium on the Archeology of the Cities of the Xia and Shang Dynasties and the 3oth Anniversary of the Discovery of the Shangcheng Site in Yanshi], ed. Zhongguo shehui kexueyuan kaogu yanjiusuo 中國社會科學院考古研究所 [Institute of Archaeology at the Chinese Academy of Social Sciences] (Beijing: Zhongguo shehui kexue chubanshe, 2014). Many other scholars who hold similar views are not listed here. Although some scholars hold different views, the majority of academics contend that Erlitou culture is Xia culture.

3 See Chang Huaiying 常懷穎, “Zaoqi Xia wenhua xueshu yantaohui jiyao 早期夏文化學術 研討會紀要 [Summary of the Symposium on Early Xia Culture]," in Zaoqi Xia wenhua yu xian Shang wenhua yanjui lunwenji, 250-58. 


\section{Defining Xia Culture}

Before discussing Xia culture, it is first necessary to clarify the meaning of the concept. Scholars have had different interpretations of what constitutes Xia culture. Some approach it from an archeological perspective, while others examine it through the lens of history or cultural anthropology.

Xia Nai 夏蒻 [1910-1985] first proposed that "Xia culture is the culture of the Xia people who lived during the Xia dynasty," ${ }^{\prime 4}$ and this view has been accepted by the majority of academics who believe that the Xia as an ethnic group was made up of the majority of the Xia people and various assimilated ethnic minorities. Some scholars disagree that Xia culture was none other than the culture of the Xia people, arguing instead that it was the culture created and used by the Huaxia 華夏 people during the Xia dynasty. Though larger in scope, it is essentially equivalent to defining the Xia as an ethnic group. However, proponents of this school of thought go one step farther, contending that "the Longshan 龍山, Xia and Shang [ca. 1600-1046 BCE] cultures in the Central Plain can be traced to the same origin." Huang Shilin 黃石林 [19222003] once stated,

When we discuss the Xia culture, we can interpret it as either the culture of the Xia people or the culture of the Xia dynasty. When discussing the culture of the Xia people, we focus on the culture's defining and archetypal qualities in the context of its cultural landscape. When discussing the culture of the Xia dynasty, we focus on its synthesizing and diversifying qualities in the context of its cultural landscape. ${ }^{5}$

This explanation is perhaps more informed by the disciplines of history and cultural anthropology.

Some scholars make a distinction between dynastic history and archeological culture by considering the question entirely from an archeological perspective. Sun Hua 孫華 represents this particular approach. Sun argues,

4 Xia Nai 夏鼎, “Tantan tantao Xia wenhua de jige wenti 談談探討夏文化的幾個問題 [On Some Issues Related to Xia Culture]," Henan wenbo tongxun 河南文博通訊, no. 1 (1978), 32-33.

5 Huang Shilin 黃石林, San lun Xia wenhua wenti 三論夏文化問題 [Three Discussions on the Question of Xia Culture], in Xiawenhua yanjiu lunji 夏文化研究論集 [Xia Culture Research: A Monograph Series], ed. Zhongguo xian Qinshi xuehui 中國先秦史學會 and Luoyangshi dier wenwu gongzuodui 洛陽市第二文物工作隊 (Beijing: Zhonghua shuju, 1996), 17 . 
Archeological chronologies are absolutely not equivalent to dynastic timelines. An archeological culture does not form suddenly because of the establishment of a particular dynasty, nor does it suddenly cease to exist the day a dynasty dies out and is replaced by a new one. Every culture goes through a process of formation, development, prosperity, decline and even destruction. If the Xia culture is the remains of the Xia people who, for the most part, established the Xia dynasty, it may have emerged before the founding of the Xia dynasty, and disappeared after its fall. It is evidently improper to use the timeline of the Xia dynasty to determine a timeline for the Xia culture. ${ }^{6}$

He went on to state,

The Xia culture as it currently stands is merely a topic for research in Chinese archeology, and has not been confirmed as a designation of an archeological culture. Researchers can provide evidence to deduce that a particular archeological culture may constitute the Xia culture, however, it is inadvisable to designate an archeological culture as the Xia culture based on a personal belief. ${ }^{7}$

Yin Weizhang 殷瑋璋 shares a similar view, arguing,

An archeological culture as a concept differs from that of a dynasty. The Xia culture already existed during the founding of the Xia dynasty. However, when the Xia dynasty started to decline, the material culture created by the people did not immediately discontinue or die out with it. On the contrary, the adherents of the former dynasty were still using and creating their culture, which allowed it to continue for some time. ${ }^{8}$

This archeological explanation seems reasonable, but it fails to take into account significant differences in the political landscape, social environment,

6 Sun Hua 孫華, Xia wenhua tansuo zhong ruogan wenti de sikao 夏文化探索中若干問題 的思考 [Reflections on Some Questions Encountered in Exploring Xia Culture], in Xiawenhua yanjiu lunji, 36 .

7 Ibid.

8 Yin Weizhang 殷瑋璋, “Guanyu Xiadai wenhua de tansuo 關於夏代文化的探索 [On Exploring the Culture of the Xia Dynasty]," in Xin Zhongguo de kaogu faxian he yanjiu 新中 國的考古發現和研究 [Archeological Discoveries and Research in New China], ed. Zhongguo shehui kexueyuan kaogu yanjiusuo (Beijing: Wenwu chubanshe, 1984), 215. 
and lifestyle before, during, and after the establishment of the dynasty, not to mention differences in the cultural landscape. In addition, to speak of an archeological culture as concurrent with a particular dynasty is to speak in general and relative terms. It allows for a short buffer period and does not imply a specific day of sudden formation or termination. Rationales of this nature are too absolute.

Similarly, scholars considering the matter from an archeological perspective hold entirely different views. Wang Lixin 王立新 contends that Xia culture is an archeological culture created and used by the Xia people of the Xia polity during the Xia dynasty, which is equivalent to Erlitou culture, a structurally stable culture that gradually formed after Qi 啟 of Xia unified the areas north and south of Mount Song 嵩. Dating before the structurally stable Erlitou culture for the final period of the Longshan ruins, as well as the ruins of the Xinzhai period, may coincide with the Xia dynasty. However, a culture of the people of the Xia polity that is not structurally stable should not be generalized as the early period of Xia culture. ${ }^{9}$ This is from a particular perspective of archeological culture that suggests that the formation of Xia culture should have lagged behind the founding of the Xia dynasty.

The author of this paper believes that, when it comes to using dynastic designations for cultures such as those of the Xia and Shang, the designations for sites of various prehistoric cultures, including those of the Xia and Shang periods, such as Erlitou, Erligang 二里岡, and Yinxu 殷墟 [Ruins of Yin] culture, differ in principle and significance. Moreover, one must take into account the disciplines of both history and archeology to understand this significance. The majority of prehistoric archeological cultures are distributed within relatively small and independent geographical units. Although adjacent cultures had some kind of impact on the level of exchange, it was limited by contemporary political conditions of time and space, and each culture displays strong independence. The same can be said for any of the other archeological cultures in the Central Plain during the time of Longshan culture. Furthermore, in manifesting a unified dynasty of unprecedented size and strength, dynastic culture had, by at least the middle and late periods of the Xia dynasty, overcome restrictions of natural geography to span the Central Plain of the original Longshan period, as well as many of its surrounding archeological cultures either partially or entirely. Thus, both dynasty and clan affiliation should be taken into account when defining cultures such as that of the Xia and Shang.

9 See Fang Yanming 方燕明, “Zaoqi Xia wenhua xueshu yantaohui’ jiyao 早·期夏文化學術 研討會紀要 [Summary of the Symposium on Early Xia Culture]," Zhongyuan wenwu 中原 文物, no. 5 (2008). 
From a chronological perspective, the Xia culture should be defined as being within the Xia dynasty, that is, from the founding of the dynasty to its fall. From a spatial perspective, Xia culture should be defined within the regions under the administration of the Xia dynasty. Otherwise, there is likely to be chaos and misunderstanding. Some scholars argue that Xia culture is not an official archeological cultural designation; thus it is inadvisable for researchers to equate the designation of Xia culture with an archeological culture on the basis of personal belief. However, use of the term "Xia culture" is unavoidable in the fields of history and archeology. As a result, the author supports the following interpretation of Xia culture, which takes into account the perspectives of both disciplines:

Xia culture refers to the remains of the culture created by the Xia people or by an ethnic group made up mostly of Xia people, in the regions under the administration of the Xia dynasty. At its core, it refers to the historic site of the Xia dynasty or polity. Thus, it is limited to a certain time (the period of the Xia dynasty), a certain place (the regions under the administration of the Xia dynasty), and a certain clan affiliation (the Xia people, an ethnic group made up mostly of Xia people, or the people of the Xia polity). It does not include the remains of other peoples living during the time of the Xia dynasty but outside regions it directly administered, nor does it include the remains of the Xia people from their origin to their fall. The cultural remains of the Xia people before the founding of, and after the fall of, the Xia dynasty, may be referred to as pre-Xia culture and post-Xia culture (or the culture of the adherents of the Xia) respectively. ${ }^{10}$

In my view, the theory of a "pre-Xia culture" is untenable. If we claim there was a "pre-Xia culture," then it is none other than the late-period Longshan culture that existed before the Xia dynasty. However, Xia culture should be a culture that is completely new. Regarding the ancestors of the Xia, we are relatively clear on father and son Gun 鯀 and Yu 禹; however, our understanding becomes less clear the higher we ascend the family tree. Figures such as Zhuanxu 顓頊, the Yellow Emperor 黃帝, and Zhurong 祝融 are part of a mythology recorded by subsequent generations and thus lack credibility. For now, it can at least be said that "pre-Xia culture," that is, the era of Gun and

10 See Zhongguo shehui kexueyuan kaogu yanjiusuo, ed., Zhongguo kaoguxue Xia Shang juan 中國考古學.夏商卷 [Chinese Archeology: The Xia-Shang Volume] (Beijing: Zhongguo shehui kexue chubanshe, 2003), 24-25. 
$\mathrm{Yu}$, is none other than the late-period Longshan culture of the Central Plain. After Gun and Yu came the culture of the Xia dynasty initiated by Qi . This new civilization was qualitatively different from Longshan culture. At the same time, we acknowledge that it is not possible to link the late-period Longshan culture of the Central Plain entirely with Erlitou culture. This missing link can be filled by the "Xinzhai period" culture. The Xinzhai period culture can be considered the formative period of Xia culture, while Erlitou culture can be considered the mature period of Xia culture.

The imperial domains of the Xia and Shang kings, as well as their surrounding areas, made up the centers of Xia and Shang culture. Some local types, which were distributed on the peripheries of these centers, were largely consistent with the centers in terms of their cultural features, but with certain differences. While Xia and Shang culture were dominant, they assimilated some elements of the indigenous cultures. While some local types emerged simultaneously with the centers, most emerged later, which demonstrates that they are the outcome of the political power of the dynasty expanding to the localities.

\section{$2 \quad$ An Alternative Chronology for the Xia Dynasty}

Regarding who established the Xia dynasty, the traditional account since the Qin [221-206 BCE] and Han [202 BCE-220 CE] dynasties has been that it was Yu the Great 大禹. The reason that modern historians began to identify Yu and Qi as figures from different periods and that Qi was the official founder of the Xia dynasty is that Yu and Qi have entirely different social natures. ${ }^{11}$ Fan Wenlan 範文瀾 [1893-1969] stated,

11 Apart from the explanation by Fan Wenlan 範文瀾 cited in this paper, see also similar views expressed by Gu Jiegang 顧頴剛, “Yu Qian Xuantong xiansheng lun gushishu 與 錢玄同先生論古史書 [Talking about Ancient History with Mr. Qian Xuantong], Dushu $z a z h i$ 讀書雜誌, no. 9 (1922); Gu Jiegang and Tong Shuye 童書業, “Gun Yu de chuanshuo: Xia Shi Kao disi zhang 鯀禹的傳說: 夏史考第四章 [The Legend of Gun and Yu: Chapter 4 of 'Verifying the History of the Xia']," Shuowen yuekan 說文月刊, no. 2-4 (1939); Guo Moruo 郭沫若, Zhongguo gudai shehui yanjiu 中國古代社會研究 [Research into Ancient Chinese Society] (Beijing: Kexue chubanshe, 1960), 337; Lv Zhenyu 呂振 羽, Shiqianqi Zhongguo shehui yanjiu 史前期中國社會研究 [Research into Prehistoric Chinese Society] (Beijing: Renwen shudian, 1934), 195-203; Jin Jingfang 金景芳, Zhongguo nuli shehui shi 中國奴隸社會史 [A History of Slavery in China] (Shanghai: Shanghai renmin chubanshe, 1983), 20-28; Li Zhongci 李忠慈, ed., Zhongguo lishi renwu shuping: gudaishi bufen shang 中國歷史人物述評: 古代史部分(上) [A Review on Chinese 
According to the Liyun 禮運 chapter of the Book of Rites [Liji 禮記], before $\mathrm{Yu}$ there were neither social classes nor exploitation. It was a time of Great Unity [datong 大同] in which people shared their property. However, after Yu came the advent of private property and a class society. Yu never sought to abolish the abdication system and was the last great leader of the time of Great Unity. The time of Small Tranquility [xiaokang 小康] should have begun with Qi.... Texts written before the Warring States Period [475-221 BCE] never use the name Yu of Xia 夏禹 but, rather, Yu, Yu the Great, and Di Yu 帝禹, and referred to Qi as Qi of Xia 夏啟 and Houqi of Xia 夏後啟. This difference demonstrates that the two figures were not from the same period. ${ }^{12}$

This represents the views of most modern historians, yet there remain some academics who insist on the traditional account that Yu was the first king of the Xia dynasty and that the history of the Xia dynasty starts with Yu. ${ }^{13}$

The course of events in which Qi succeeded Yu has been described in various ways in documentary sources. The transformation from an abdication system to a hereditary system is a major historical transition during which

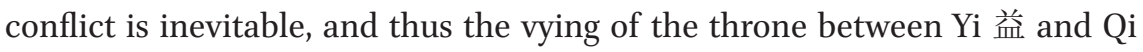
may be more consistent with historical facts. That being said, it is not as if Yu passed on his throne directly to Qi. This is relatively consistent with various documentary accounts and should be factual. To conclude, during the time of $\mathrm{Yu}$, the system of primitive democratic elections of the tribes and tribal alliance leaders played a certain role or at the very least was nominally maintained. Furthermore, successors required a certain amount of support from the people. In other words, they needed to have the prestige and ability to rally the support of their clan, tribe, or alliance. Without it, they would not be

Historical Figures: Ancient History Volume, part 1] (Tianjin: Tianjin shehui kexueyuan chubanshe, 1990), 14.

12 Fan Wenlan 範文瀾, Zhongguo tongshi diyi bian 中國通史(第一編) [History of China, vol. 1] (Beijing: Renmin chubanshe, 2009), 29, 32.

13 The Xia-Shang-Zhou Chronology Project determined that 2070 BCE was the first year of the Xia dynasty and that reckoning for the first generation of Xia kings starts with Yu. See Xia-Shang-Zhou duandai gongcheng zhuanjia zu 夏商周斷代工程專家組, XiaShang-Zhou duandai gongcheng 1996-200o nian jieduan chengguo baogao jianben 夏商周 斷代工程 1996-2000 年階段成果報告(簡本) [The Xia-Shang-Zhou Chronology Project Report for the years 1996-200o (abridged)] (Beijing: Shijie tushu chuban gongsi, 2000), 86; Zhu Shaohou 朱紹侯 et al., ed., Zhongguo gudaishi shang 中國古代史(上) [Ancient Chinese History, part 1] (Fuzhou: Fujian renmin chubanshe, 2006), 31; Zhan Ziqing 詹子慶, Xiashi yu Xiadai wenming 夏史與夏代文明 [History of the Xia Dynasty and Its Civilization] (Shanghai: Shanghai kexue jishu wenxian chubanshe, 2007), 95-96. 
able to achieve "the succession of the lords or the Son of Heaven that conforms with the rules of propriety."14 And so the power of the state shifted from being public to being private and in the hands of the royal family.

In this way, it seems reasonable to incorporate Yu's reign into the primitive democratic system phase in the final period of primitive society, leaving us to conclude that Qi was the initiator of the Xia dynasty.

Regarding the first year of the Xia period, both traditional documentary research and contemporary, multidisciplinary research begin their calculations with the Zhou dynasty [1046-256 в Се]. The first year of the Xia dynasty is obtained by superimposing year counts for the Western Zhou [1046-256 вСE], Shang, and Xia dynasties on the first year of the Eastern Zhou [770-256 в Се ] dynasty.

Documentary sources offer a number of year counts for the Xia, Shang, and Zhou periods. The Xia dynasty has five or six different ones, generally between 431 and 483 years. Two year counts are most commonly used by scholars. The first is 471 years, the count provided in the Ancient Text of the Bamboo Annals [Guben zhushu jinian 古本竹書紀年]. The second is 431 or 432 years, which are the two most frequently quoted counts in ancient texts. Two explanations have been offered as to why these two counts have a 40-year difference. The first is that the count of 471 years includes the "kingless" period in which Hou Yi 後翠 and Han Zhuo 寒浞 represented Xia, which the count of 431 years does not include. The second is that the count of 471 years is reckoned from Shun's abdication to $\mathrm{Yu}$, while the count of 431 years is reckoned from the first year of Yu's reign.

Despite inconsistency in the documentary sources, modern researchers can support their arguments by integrating archeological, oracle bone, and bronze inscription materials, as well as ancient astrological calendars, with the dating methods in modern physics. ${ }^{15}$ They adopt the perspectives of their own disciplines or academic systems, with their own understanding and selection criteria, and thus hold a range of views when it comes to the year counts and first years of the Xia, Shang, and Zhou dynasties. Consider, for example, the dynastic year counts proposed by the Xia-Shang-Zhou Chronology Project. It did not adopt the explanation set out in the Ancient Text of the Bamboo Annals regarding the

\footnotetext{
14 Zheng Xuan 鄭玄, annot., Kong Yingda 孔穎達, comm., “Liji Zhengyi 禮記正義 [Interpretations of the Book of Rites]," in Shisanjing zhushu 十三經注疏 [Commentary on the Thirteen Classics], ed. Ruan Yuan 阮元 (Shanghai: Shanghai guji chubanshe, 1997), 1414.

15 See Xia-Shang-Zhou duandai gongcheng zhuanjia zu, The Xia-Shang-Zhou Chronology Project Report for the years 1996-200o; Zhongguo shehui kexueyuan kaogu yanjiusuo, Zhongguo kaoguxue Xia Shang juan; Chang Huaiying, "Summary of the Symposium on Early Xia Culture."
} 
year counts for the Shang and Zhou dynasties, instead adopting the following explanation of the Xia dynasty: "From Yu to Jie 桀, there were seventeen generations, with kings and without, lasting 471 years." ${ }^{16}$ However, the project did not provide any rationale as to why it favored one explanation over the other. Regarding the first years of the Western Zhou dynasty, views among scholars do not differ very much, from a few years, to yingver ten years, to a maximum of approximately 100 years. ${ }^{17}$ Regarding the first years of the Xia and Shang dynas-

16 Fan Xiangyong 範祥雍, ed., Guben zhushu jinian jijiao dingbu 古本竹書紀年輯校訂補 [Supplement of Compiler on The Ancient Text of the Bamboo Annals] (Shanghai: Shanghai renmin chubanshe, 1957), 17.

17 See Zhu Fenghan 朱鳳瀚 and Zhang Rongming 張榮明, ed., "Xizhou zhuhou wang niandai zhushuo yilanbiao 西周諸侯王年代諸說一覽表 [A Table of the Various Theories of the Chronology of the Kings and Lords of the Western Zhou Dynasty]," in Xizhou zhu wang niandaiyanjiu 西周諸王年代研究 [Research into the Chronology of the Kings of the Western Zhou Dynasty] (Guiyang: Guizhou renmin chubanshe, 1998). Note that this table summarizes the findings of all research published before October 1997 by scholars in and outside China regarding the first year of the Western Zhou dynasty. Among these findings, the earliest first year is $1130 \mathrm{BCE}$, and the latest is $1027 \mathrm{BCE}$, a difference of 103 years. The most notable first years in order of publication are as follows: Shinzo Shinjo: 1066 в Shinzo Shinjo 新城新藏, “Zhou chu zhi niandai 周初之年代 [A Chronology of the Early Zhou Period]," in Dongyang tianwenxueshi yanjiu 東洋天文學史研究 [Research into the History of East Asian Astronomy], trans. Shen Xuan 沈䅧 (Shanghai: Zhonghua xueyishe, 1933); Wu Qichang: 1122 BCE; see Wu Qichang 吳其昌, “Jinwen yinianbiao 金文疑年表 [A Table of Suspected Years in Chinese Bronze Inscriptions]," in Jinwen lishuo shuzheng, juan 6, 7 金文歷朔疏證(卷六、卷七) [A Calendar Verification of Bronze Inscriptions, vols. 6, 7)] (Shanghai: Shangwu yinshuguan, 1936); Ding Shan: 1030 вCE; see Ding Shan 丁山, “Wen Wu Zhougong yinian 文武周公疑年 [Suspected Years for King Wen, King Wu and Duke of Zhou]," Zeshan banyuekan 責善半月刊, no. 1-2 (1941); Dong Zuobin: 1111 BCE; see Dong Zuobin 董作賓, “Xizhou nianlipu 西周年曆譜 [An Annual Calendar for the Western Zhou Dynasty]," in Zhongyang yanjiuyuan lishi yuyan yanjiusuo jikan, di ershisan ben, xia 中央研究院歷史語言研究所集刊(第二十三本下) [Academia Sinica, Research Department of History and Language, vol. 23, part 2] (1952); Tang Lan: 1075 BCE; Tang Lan 唐蘭, “Zhongguo gudai lishi shang de niandai wenti 中國古代歷史上的年 代問題 [The Question of Chronology in Ancient Chinese History]," Xin jianshe 新建設, no. 3 (1955); Chen Mengjia: 1027 BCE; see Chen Mengjia 陳夢家, "Shang-Yin yu Xia-Zhou de niandai wenti 商殷與夏周的年代問題 [The Question of Chronology in the ShangYin and Xia-Zhou Periods]," Lishi yanjiu 歷史研究, no. 2 (1955); Rong Mengyuan: 1055 BCE; see Rong Mengyuan 榮孟源, “Shitan Xizhou jinian 試談西周紀年 [A Tentative Discussion on the Year Numbering System of the Western Zhou Dynasty]," Zhonghua wenshi luncong 中華文史論叢, no. 1 (1980); Liu Qiyi: 1075 BCE; see Liu Qiyi 劉啟益, “Xizhou jinian tongqi yu Wuwang zhi Liwang de zaiwei nianshu 西周紀年銅器與武王至厲王 的在位年數 [Western Zhou Bronzeware Chronology and Reign Year Counts from King Wu to King Li]," Wenshi 文史, no. 13 (1982); Ma Chengyuan: 1105 BCE; see Ma Chengyuan 馬承源, “Xizhou jinwen he lishi de yanjiu 西周金文和歷史的研究 [Research on the Bronze Inscriptions and History of theWestern Zhou Dynasty],"in Shanghaibowuguanjikan 
ties, views among scholars differ considerably, from over 100 years to even 400 or 500 years. Take, for example, Zheng Guang 鄭光, who derived many of his views on ancient history from the Triple Concordance System [San tong li 三統 歷]. Zheng used this book, which was written by the Western Han historian Liu Xin 劉歆 [50-23 BCE], as a basis for collating, differentiating, and analyzing chronological material available in ancient texts, ultimately determining that the Xia dynasty existed from the twenty-third to the eighteenth centuries вСЕ. ${ }^{18}$ This chronology can be seen as an extreme example that places the Xia period relatively early in history.

An academic consensus has now been reached that Erlitou culture is the basis of Xia culture. However, differing opinions remain regarding the chronology of Erlitou culture. In the book Chinese Archeology, the carbon-14 dating result that had already been released was checked against the archeological culture chronological sequence. ${ }^{19}$ The assessment was that the Erlitou culture periodic range was from the mid-nineteenth century to the mid-sixteenth century BCE, a range commonly cited by academics. However, the dates determined by the Chronology Project based on the dating data for the late-period Longshan culture, the Xinzhai period, and Erlitou culture were much later than in previous chronologies. Xu Hong described the subsequent response from academia as "earth-shattering." 20 The new excavation report Erlitou concluded on the basis of new dating results that Erlitou culture existed from 1750 to 1530 BCE. ${ }^{21}$ It pushed the upper limit back more than one hundred years and reduced its span to just over 200 years.

Because volcanoes in China are undeveloped, there are no geological formations that feature ancient ruins associated with volcanic ash coverage or volcanic rock formation. As a result, it is not possible to obtain relatively accurate dating based on the radioactive decay of minerals within volcanic ash. The margin for error in other dating methods is considerable. Historical periods in particular require more precise chronologies. However, a calendar chronology

上海博物館集刊 [Periodical of Shanghai Museum](Shanghai: Shanghai guji chubanshe, 1982).

18 Zheng Guang 鄭光, Guanyu Zhongguo gushi de niandaixue wenti 關於中國古史的年代 學問題 [On the Question of Chronology in Ancient Chinese History], in Xiawenhua yanjiu lunji, 284-301.

19 Zhongguo shehui kexueyuan kaogu yanjiusuo, Zhongguo Kaoguxue Xia Shang juan, $24-25$.

20 Xu Hong 許宏, “Erlitou wenhua juluo dongtai saomiao 二里頭文化聚落動態掃描 [Scanning the Dynamics of the Erlitou Culture Settlements]," in ZaoqiXia wenhua yu xian Shang wenhua yanjui lunwenji, 3 .

21 Zhongguo shehui kexueyuan kaogu yanjiusuo, ed., Erlitou二里頭 (1999-2006) (Beijing: Wenwu chubanshe, 2014). 
adjusted according to carbon-14 dating often has a larger error than carbon dating alone, because a carbon dating error range of a few decades can be manifested as an error range of more than one hundred years on a calendar. ${ }^{22}$ Although carbon-14 dating technology is constantly being improved, the problem of errors is unavoidable. During the Symposium on Early Xia Culture held in July 2008 in Zhengzhou 鄭州, many scholars called into question the use of carbon-14 dating to argue for a later chronology for Erlitou culture. Most scholars argued that data obtained from carbon-14 dating cannot be regarded as primary evidence for archeological researchers and should be used only for reference. They also argued that researchers should be wary of preconceptions that serve archeological views. A great deal of uncertainty surrounds carbon samples that lack cultural features in terms of their stratigraphic position, and chronological sequences obtained by a series of samples may not be entirely credible.

However, all the dating results showed that Erlitou culture was significantly later than the first year of the Xia dynasty as stated in traditional accounts, and it should be acknowledged that the basic chronological sequence for the late-period Longshan, Xinzhai, and Erlitou culture was verified by both archeological and dating methods. Thus many scholars believe that Erlitou culture is none other than the culture of the Xia dynasty during its middle and late periods. ${ }^{23}$ At its earliest stage, Xia culture can be identified from the late-period Longshan culture in Henan Province. Some scholars believe that Phase III of Wangwan 王灣 culture is none other than the earliest stage of Xia culture. ${ }^{24}$

22 Zhang Xuelian 張雪蓮 and Qiu Shihua 仇士華 et al., "Xinzhai Erlitou Erligang wenhua kaogu niandai xulie de jianli yu wanshan 新些一二里頭一二里岡文化考古年代序列 的建立與完善 [The Establishment and Improvement of the Xinzhai-Erlitou-Erligang Culture Chronology]," Kaogu 考古, no. 8 (2007).

23 See Wu Ruzuo 吳汝祚, “Guanyu Xia wenhua ji qi laiyuan de chubu tansuo 關於夏文化 及其來源的初步探索 [A Tentative Exploration of Xia Culture and Its Origins],” Wenwu 文物, no. 9 (1978); Xu Shunzhan 許順湛, “Xiadai wenhua de zai tansuo 夏代文化的再 探索 [A Re-Exploration of Xia Culture]," Henan wenbo tongxun, no. 3 (1979); Li Xiandeng 李先登, “Erlitou yizhi yu Xia wenhua 二里頭遺址與夏文化 [The Erlitou Site and Xia Culture]," in Erlitou yizhi yu Erlitou wenhua yanjiu 二里頭遺址與二里頭文化研究 [Research into the Erlitou Site and Erlitou Culture], ed. Du Jinpeng 杜金鵬 and Xu Hong (Beijing: Kexue chubanshe, 2006); Zhang Li 張莉, “Xiadai zaoqi ducheng yanjiu 夏代早 期都城研究 [Research into the Early Capital of Xia Dynasty]," in Research into the Erlitou Site and Erlitou Culture.

24 See Zhao Zhiquan 趙芝荃 and Liu Zhongfu 劉忠伏, “Shitan Yanshi Shangcheng de shijian niandai bing jian lun Xia wenhua de shangxian 試談偃師商城的始建年代 並兼論夏文化的上限 [A Tentative Discussion on the Founding Year of Shangcheng, Yanshi, and the Upper Limit of Xia Culture]," in Huaxia wenming, diyiji 華夏文明(第 一集) [Chinese Civilization, vol. 1], ed. Tian Changwu 田昌五 (Beijing: Peking University 
Others argue that the "Xinzhai period" site, which exhibits transitional qualities from the late-period Longshan culture to the Erlitou culture, is in fact the earliest stage of Xia culture. ${ }^{25}$ However, some scholars still insist that Phase I of Erlitou culture is the earliest stage of Xia culture. ${ }^{26}$ Longshan and Erlitou culture are intrinsically different and are not part of the same archeological culture. Moreover, the early stage of the Xinzhai period site in fact is part of the late period of Longshan culture, while the late stage is part of Phase I of Erlitou culture.

Although various explanations are in competition, their differences cannot be resolved. Thus, it may be constructive to consider them from a different perspective. Japanese archeologist Iijima Taketsugu 飯島武次 [b. 1943] performed

Press, 1987); Zhao Zhiquan, Lun Xia wenhua qizhi niandai de wenti 論夏文化起、 止年代的問題 [On the Beginning and End Chronology of the Xia Culture], in Xiawenhua yanjiu lunji, 277-83; An Jinhuai 安金槐, “Yuxi Xiadai wenhua chutan 豫西夏代文化初探 [A Tentative Exploration of Xia Culture in Western Henan Province]," Zhongguo lishi bowuguan guankan 中國歷史博物館館刊, no. 1 (1979); An Jinhuai, Shilun Yuxi diqu Longshan wenhua leixing zhong wanqi yu Xiadai wenhua zaoqi de guanxi 試論豫西 地區龍山文化類型中晚期與夏代文化早期的關係 [A Tentative Discussion on the Relationship between the Middle and Late Periods of Longshan Culture in Western Henan Province and Early-Period Xia Culture], in Xiawenhua yanjiu lunji, 3-10; Wang Kelin 王克 林, “Cong Longshan wenhua de jianzhu jishu tansuo Xia wenhua 從龍山文化的建築技 術探索夏文化 [Exploring Xia Culture from the Construction Technology of Longshan Culture]," Shanxi daxue xuebao (zhexue shehui kexue ban) 山西大學學報 (哲學社會科 學版), no. 3 (1980).

25 See Fang Yousheng 方西生, “Luelun Erlitou yizhi diyi qi yicun yu Xiadai jinian: jian ping Erlitou wenhua yiqi yicun yu Xia wenhua chushi 略論二里頭遺址第一期遺存與夏代 紀年一兼評〈二里頭文化一期遺存與夏文化初始〉 [A Brief Discussion of Phase I of the Erlitou Site and the Chronology of the Xia Dynasty, with a Review of 'Phase I of Erlitou Culture and the Origins of Xia Culture']," in Zhongguo shiqian kaoguxue yanjiu: zhuhe Shi Xingbang xiansheng kaogu banshiji ji bazhi huadan wenji 中國史前考古 學研究一祝賀石興邦先生考古半世紀暨八秩華誕文集 [Research into Chinese Prehistorical Archeology: Collected Works Celebrating Mr. Shi Xingbang's Half-Century Contribution to Archeology and His 8oth Birthday] (Xi'an: Sanqin chubanshe, 2004); Zhang Guoshuo 張國碩, “Xia jinian yu Xia wenhua yicun chuyi 夏紀年與夏文化遺存媰議 [My View on the Chronology of the Xia Dynasty and the Xia Culture Site]," Zhongguo wenwu bao 中國文物報, no. 20 (2001); Zhang Guoshuo, "Lun Erlitou yizhi de xingzhi 論二裡頭遺址的性質 [On the Nature of the Erlitou Site]," in Erlitou yizhi yu Erlitou wenhua yanjiu.

26 See Chen Xu, “Guanyu Xia wenhua wenti de yi dian renshi 關於夏文化問題的一點認 識 [Interpretations of the Xia Culture Question]," Zhengzhou daxue xuebao (zhexue shehui kexue ban) 鄭州大學學報(哲學社會科學版), no. 5 (1980); Chen Xu, "Erlitou yiqi wenhua shi zaoqi Xia wenhua”; Li Weiming 李維明, “Erlitou wenhua yi qi yicun yu Xia wenhua chushi 二里頭文化一期遺存與夏文化初始 [Phase I of Erlitou Culture and the Origins of Xia Culture]," Zhongyuan wenwu, no. 1 (2002). 
a year-count calculation based on various generation counts. ${ }^{27} \mathrm{Liu} \mathrm{Xu}$ 劉緒 [b. 1949] discussed the issue further but rather incautiously. He examined the Zhou-dynasty male coming-of-age standard and, under the assumption that each generation lasted twenty years on average, proposed that the Xia dynasty had lasted 280 years. He then added the element of agnatic seniority (i.e., adding ten years for a generation in which a younger brother inherits the throne) to arrive at a year count for the Xia period of 310 years. Counting back from the first year of the Eastern Zhou dynasty, he concluded that the first year of the Xia dynasty was 1730 вCE. Considering that twenty-year-old married men may not necessarily produce offspring during the year of their marriage that after marriage men on average give birth to their first son within three years, and therefore reckoning each generation as twenty-three years long, he concluded that the year count for the Xia dynasty is $35^{2}$ years and that its first year was 1856 в С. If a generation is calculated as thirty years long, and agnatic seniority is not taken into account, then the year count for the Xia dynasty is 420 years, and its first year is $2030 \mathrm{BCE} .^{28}$ This conclusion is relatively close to that of traditional accounts with a year count for the Xia dynasty of 471 years, as well as the first year of 2070 BCE suggested by the Chronology Project.

If we assume that each generation is thirty years long, then it must be assumed that Xia kings married and had children at around the age of thirty and that the Shang and Zhou kings, like the Xia kings, must have married and had children later. This claim, however, does not stand up to reason, unless it can be argued that the account given in the Ancient Text of the Bamboo Annals that the Xia dynasty had seventeen kings in fourteen generations is unreliable and omitted a number of generations. The lineage for the Shang recorded in the Records of the Grand Historian [Shiji 史記] has been verified by oracle bone inscriptions. The lineage for the Western Zhou dynasty has been confirmed by bronze inscriptions. The lineage for the Jin 晉 has been verified by the cemetery of the Marquis of Jin [Jin hou mudi 晉侯墓地]. Therefore, the lineage for the Xia dynasty should be more or less credible. Even so, the first years of the Xia, Shang, and Zhou dynasties are not very late, and each reaches the earliest limit. For example, according to the Ancient Text of the Bamboo Annals, the Xia dynasty spanned 471 years, and the average length of each generation was thirty-four years, so the Xia kings should have married and had children much later in their lives, at around age thirty or older.

\footnotetext{
27 Iijima Taketsugu 飯島武次, Ka-In bunka no kōkogaku kenkyū 夏殷文化の考古學研究 [Archeological Research into the Culture of the Xia and Yin Dynasties] (Tokyo: Yamakawa, 1985).

28 See Liu Xu, "Dui tantao zaoqi Xia wenhua de ji dian kanfa," 7-15.
} 
Although this is mere conjecture, it at least proposes a possibility. The author believes that one can be more precise and that statistics can be collected on the year counts of monarch reigns after the Eastern Zhou dynasty to arrive at a generational average year count by excluding short-lived dynasties and including the Eastern Zhou, Western and Eastern Han, Tang [618-907], Song [960-1279], Ming [1368-1644], and Qing [1636-1912] dynasties. In the aforementioned dynastic year-count statistics, the Eastern Han dynasty, at under 200 years, is the shortest and has a slightly higher generational average year count of twenty-eight years, in comparison with the Tang dynasty generational average year count of 19.3 years. The generational average year counts for the other dynasties are more than twenty years on average and generally fluctuate around the twenty-five-year mark. The further one goes back in ancient history, the shorter is life expectancy. Thus, the generational year count for people living during the Xia, Shang, and Zhou dynasties cannot possibly be more than thirty years. For example, a generational average year count is calculated (Eastern Zhou 25.8 + Western Zhou $21+$ Eastern Han $28+$ Tang $19.3+$ Song $26.7+$ Ming 23 + Qing $26.9=170.7$ years, $170.7 / 7 \approx 24.4$ years), and the year counts and first years for the Xia, Shang, and Western Zhou dynasties are deduced (see Table 1).

The first-year date of the Western Zhou dynasty proposed in this table is merely one year different from the Chronology Project's estimation of the year in which King Wu of Zhou overthrew the Shang dynasty. It also happens to be the year in which the Western Zhou 周武王 dynasty began. This demonstrates that the calculation method used in this paper has a certain degree of reliability.

Various dynasties have all had succession by brothers, even uncles and nephews. The Western Zhou dynasty was similar to successive generations and so need not be taken into consideration. Agnatic seniority was commonplace only in the Shang dynasty and so needs to be considered. Regarding the lineage of the Shang dynasty, according to the "Annals of Yin" [Yin benji 殷本紀] chapter in the Records of the Grand Historian, agnatic seniority was followed for nine generations, whereas, according to the oracle bone inscriptions, it was followed for only eight generations. Succession by the younger brother occurred in later generations. For example, it occurred for one generation in the Western Zhou dynasty. Thus, the difference between one and two generations can be disregarded. Assuming that agnatic seniority was followed for eight generations, according to Liu $\mathrm{Xu}$, the year count for every generation on the basis of succession from father to son adds another ten years, adding a total of eighty years. In light of the fact that in later generations one brother succeeding the other was mostly the norm, whereas during the Shang dynasty three or four brothers succeeding one another also occurred, it is possible that the reign of 
TABLE 1 Year counts and first years of the Xia, Shang, and Western Zhou dynasties (deduced on the basis of a generational average year count of 25 years)

\begin{tabular}{|c|c|c|c|}
\hline Dynasty & Year count & First year & Comments \\
\hline $\begin{array}{l}\text { Western } \\
\text { Zhou }\end{array}$ & $\begin{array}{l}11 \text { generations } \\
\times 25 \text { years }=275 \\
\text { years }\end{array}$ & $\begin{array}{l}1045 \text { ВСЕ }(770 \text { ВСЕ + } \\
275)\end{array}$ & $\begin{array}{l}\text { The Chronology Project } \\
\text { deduced that King Wu of Zhou } \\
\text { overthrew the Shang dynasty in } \\
\text { 1046 вСЕ. }\end{array}$ \\
\hline \multirow[t]{2}{*}{ Shang } & $\begin{array}{l}17 \text { generations } \\
\times 25 \text { years }=425 \\
\text { years }\end{array}$ & $\begin{array}{l}1470 \text { ВСЕ (1045 ВСЕ } \\
+425)\end{array}$ & $\begin{array}{l}\text { Agnatic seniority is not taken } \\
\text { into account. }\end{array}$ \\
\hline & $\begin{array}{l}425 \text { years }+130 \\
\text { years }=555 \text { years }\end{array}$ & $\begin{array}{l}\text { 16оо ВСЕ }(1470 \text { ВСЕ } \\
+130)\end{array}$ & $\begin{array}{l}\text { Agnatic seniority followed for } \\
8 \text { or } 9 \text { generations. } 130 \text { years is } \\
\text { added. } \\
\text { Chronology Project: The Shang } \\
\text { year count adopted the theory } \\
\text { of } 29 \text { kings over } 496 \text { years. It } \\
\text { added Di Yi 帝乙 and Di Xin 帝 } \\
\text { 辛, who reigned consecutively } \\
\text { for } 56 \text { years, to obtain a year } \\
\text { count of } 55^{2} \text { years, determin- } \\
\text { ing the first year of the Shang } \\
\text { dynasty as } 1598 \text { BCE and } \\
\text { rounding it up to } 16 \text { oо BCE. }\end{array}$ \\
\hline \multirow[t]{2}{*}{ Xia } & $\begin{array}{l}13 \text { generations } \\
\times 25 \text { years }=325 \\
\text { years }\end{array}$ & $\begin{array}{l}1795 \text { ВСЕ (1470 ВСЕ } \\
+325)\end{array}$ & $\begin{array}{l}\text { Agnatic seniority is not taken } \\
\text { into account. }\end{array}$ \\
\hline & $\begin{array}{l}345 \text { years }(325 \\
\text { years }+20 \text { years })\end{array}$ & $\begin{array}{l}1945 \text { ВСЕ (160о ВСЕ } \\
+345)\end{array}$ & $\begin{array}{l}\text { Agnatic seniority is followed for } \\
\text { three generations. By deleting } \\
\text { an extra generation for the fol- } \\
\text { lowing generations, another } 20 \\
\text { years was added. } \\
\text { The Chronology Project } \\
\text { adopted the theory that Xia } \\
\text { began with Yu in } 471 \text {, as stated } \\
\text { in the Ancient Text of the } \\
\text { Bamboo Annals, obtaining a } \\
\text { tentative first year of the Xia } \\
\text { dynasty of } 207 \text { ВСЕ. }\end{array}$ \\
\hline
\end{tabular}


two brothers succeeding each other may have been longer. For example, the Chronology Project used its findings of parallelism in the sacrificial sequences [sipu 祀譜] of late-period Shang dynasty oracle bone inscriptions to determine that the generation of $\mathrm{Zu} \mathrm{Geng}$ 祖庚 and $\mathrm{Zu} \mathrm{Jia}$ 祖甲 and the generation of Lin Xin 桌辛 and Kang Ding 康丁 reigned consecutively for forty-four years with an average generation length of twenty-two years, which is close to the average length of twenty-five years. However, the three brothers Pan Geng 盤庚 (after moving the capital of the Shang dynasty to Yin), Xiao Xin 小辛, and Xiao Yi 小乙 succeeded one another to the throne, with a total reign period of fifty years, which is double the twenty-five-year average generation length. In other words, a further ten years is added to this generation, plus another fifteen years. However, if one takes into account the time before Pan Geng moved the capital to Yin and the reign of Pan Geng's brother Yang Jia 陽甲, then this generation may have lasted more than sixty years. Moreover, in three or four instances among the Shang dynasty kings, the throne was passed among three or four brothers. With this assumption, it would be reasonable to add another 50 years or so on top of the 80-year count for the Shang dynasty, and then add another 130 years or so without considering the possibility of agnatic seniority. This calculation is as follows: Year count for the Shang dynasty: 425 years +130 years $=555$ years; first year for the Shang dynasty: 1045 BCE +555 years $=$ 1,600 years.

Regarding year counts for the Shang dynasty, documentary sources record 629,576 , and 496 , as well as approximations of 600 and 500 in sacrificial records. The Collected Commentaries on the Records of the Grand Historian [Shiji jijie 史記集解], quotes the Ancient Text of the Bamboo Annals: "Tang was instructed by the heavens to destroy the Xia. [Altogether] there were 29 kings, with [the Shang] reigning 496 years." 29 It is a year count that spans twenty-nine kings, fewer than the thirty kings in the Shang stated in the "Annals of Yin" chapter in the Records of the Grand Historian, although if Tai Ding 太丁, who died before ascending the throne, is included, the total would be thirty-one. There are two possible explanations for this. The first is that they counted from Tang 湯 to Wen Ding 文丁 (King Wen of Zhou 周文王, as instructed by the heavens, proclaimed himself king) to arrive at twenty-nine to the exclusion of Di Yi and Di Xin. The second is that they counted from Tang to Di Xin ascending the throne to arrive at twenty-nine, without including Da Ding 大丁 and Di Xin. Based on parallelism in late-Shang sacrificial sequences, the Chronology Project concluded that Di Xin held the throne for thirty years and Di Yi for twenty-six years. Adding the reigns of the two kings together, that totals fifty-six years.

29 Fan Xiangyong, Supplement of Compiler of The Ancient Text of the Bamboo Annals, 24. 
According to the first explanation, a year count for the Shang dynasty of $55^{2}$ years is determined. The 1046 вСЕ date of King Wu of Zhou overthrowing the Shang pushed the first year for the Shang dynasty back to 1598 в to the second explanation, by merely adding Di Xin's 30 years, a year count for the Shang dynasty of $5^{26}$ years can be determined, with its first year at 1572 в Се. The year count and first year for the Shang dynasty as determined by the first explanation differs only two or three years from the findings in this paper. The Chronology Project undertook a comprehensive analysis of various documentary theories, consulted relevant dating data, and determined 1600 вСE as an approximate first year of the Shang dynasty.

During the Xia dynasty, agnatic seniority was followed for three generations. By deleting the extra generation of later generations, then adding another twenty years, a year count for the Xia dynasty of 345 (225 years +20 years) is determined, with its first year being 1925 BCE (1795 BCE +130 years). This estimate puts the first year of the Xia dynasty, reckoning from Qi, in the middle of the twentieth century все.

\section{Works Cited}

An Jinhuai 安金槐. “Yuxi Xiadai wenhua chutan 豫西夏代文化初探 [A Tentative Exploration of the Xia Culture in Western Henan Province]." Zhongguo lishi bowuguan guankan 中國歷史博物館館刊, no. 1 (1979): 24-29.

Beijing daxue zhendan gudai wenming yanjiu zhongxin 北京大學震旦古代文明研 究中心 [Peking University Zhendan Center for Ancient Civilizations Research] et al., ed. ZaoqiXia wenhua yu xian Shang wenhua yanjiu lunwenji 早期夏文化與先商 文化研究論文集 [A Collection of Essays on Early-Period Xia Culture and Pre-Shang Culture Research]. Beijing: Kexue chubanshe, 2012.

Chen Huaiquan 陳懷荃. "Jianlun da Yu zhishui he Xia wangchao de jianli 簡論大禹 治水和夏王朝的建立 [A Brief Discussion on Yu the Great's Flood Control and the Founding of the Xia Dynasty]." In Mianxiang xin shiji de Zhongguo lishi dilixue: 2000 nian guoji zhongguo lishi dili xueshu taolunhui lunwenji 面向新世紀的中國歷史地 理學—2000 年國際中國歷史地理學術討論會論文集 [Chinese Historical Geography in the New Century: Proceedings of the 2000 Symposium on International Chinese Historical Geography], ed. Fudan daxue lishi dili yanjiu zhongxin 復旦大學歷史地 理研究中心, 170-179. Jinan: Qilu shushe, 2001.

Chen Mengjia 陳夢家. “Shang-Yin yu Xia-Zhou de niandai wenti 商殷與夏周的年代 問題 [The Question of Chronology in the Shang-Yin and Xia-Zhou Periods]." Lishi yanjiu 歷史研究, no. 2 (1955): 53-77. 
Chen Xu 陳旭. “Guanyu Xia wenhua wenti de yi dian renshi 關於夏文化問題的一點認 識 [Interpretations of the Xia Culture Question]." Zhengzhou daxue xuebao (zhexue shehui kexue ban) 鄭州大學學報(哲學社會科學版), no. 5 (1980): 67-72+79.

Ding Shan 丁山. "Wen Wu Zhougong yinian 文武周公疑年 [Suspected Years for King Wen, King Wu and Duke of Zhou]." Zeshan banyuekan 責善半月刊, no. 1-2 (1941): 2-8.

Dong Zuobin 董作賓. “Xizhou nianlipu 西周年曆譜 [An Annual Calendar for the Western Zhou Dynasty]." Zhongyang yanjiuyuan lishi yuyan yanjiusuo jikan, diershisan ben, xia 中央研究院歷史語言研究所集刊(第二十三本下) [Academia Sinica, Research Department of History and Philology, vol. 23, part 2] (1952): 681-76o.

Du Jinpeng 杜金鵬 and Xu Hong 許宏, ed. Erlitou yizhi yu Erlitou wenhua yanjiu 二里頭遺址與二里頭文化研究 [Research into the Erlitou Site and the Erlitou Culture]. Beijing: Kexue chubanshe, 2006.

Duan Tianjing 段天璟. Erlitou wenhua shiqi de Zhongguo 二里頭文化時期的中國 [China during the Time of Erlitou Culture]. Beijing: Shehui kexue wenxian chubanshe, 2014 .

Fan Wenlan 範文瀾. Zhongguo tongshi, diyi bian 中國通史(第一編) [History of China, vol. 1]. Beijing: Renmin chubanshe, 2009.

Fan Xiangyong 範祥雍, ed. Guben zhushu jinian jijiao dingbu 古本竹書紀年輯校訂補 [Supplement of Compiler on the Ancient Text of the Bamboo Annals]. Shanghai: Shanghai renmin chubanshe, 1957.

Fang Yanming 方燕明. “'Zaoqi Xia wenhua xueshu yantaohui’ jiyao 期“夏文化學術研 討會, 紀要 [Summary of the Symposium on Early Xia Culture]." Zhongyuan wenwu 中原文物, no. 5 (2008): 33-38.

Fang Yousheng 方西生. “Luelun Erlitou yizhi diyi qi yicun yu Xiadai jinian: jian ping Erlitou wenhua yiqi yicun yu Xia wenhua chushi 略論二里頭遺址第一期遺存與夏代 紀年一兼評〈二里頭文化一期遺存與夏文化初始〉 [A Brief Discussion of Phase I of the Erlitou Site and the Chronology of the Xia Dynasty, with a Review of 'Phase I of the Erlitou Culture and the Origins of the Xia Culture']." In Zhongguo shiqian kaoguxue yanjiu: zhuhe ShiXingbang xiansheng kaogu banshijiji bazhi huadan wenji 中國史前考古學研究一祝賀石興邦先生考古半世紀暨八秩華誕文集 [Research into Chinese Prehistorical Archeology: Collected Works Celebrating Mr. Shi Xingbang's Half-Century Contribution to Archeology and his 8oth Birthday], 509-515. Xi'an: Sanqin chubanshe, 2004.

Gu Jiegang 顧頡剛. “Yu Qian Xuantong xiansheng lun gushishu 與錢玄同先生論古史 書 [Talking about Ancient History with Mr. Qian Xuantong].” Dushu zazhi 讀書雜 誌, no. 9 (1922): 3-4.

Gu Jiegang 顧頴剛 and Tong Shuye 童書業. “Gun Yu de chuanshuo: Xia Shi Kao disi zhang 鯀禹的傳說: 夏史考第四章 [The Legend of Gun and Yu: Chapter 4 
of 'Verifying the History of the Xia']." Shuowen yuekan 說文月刊, no. 2-4 (1939): 43-96.

Gu Jiegang 顧頡剛 and Tong Shuye 童書業. “Xiashi Sanlun: Xia Shi Kao diwu, liu, qi zhang 夏史三論：夏史考第五、六、七章 [Three Theories on the Xia Dynasty: 'Verifying the History of the Xia' Chapters 5,6 and 7]." Shixue nianbao 史學年報, no. 3 (1936): 1-103.

Guo Moruo 郭沫若. Zhongguo gudai shehui yanjiu 中國古代社會研究 [Research into Ancient Chinese Society]. Beijing: Kexue chubanshe, 196o.

Huang Shilin 黃石林. San lun Xia wenhua wenti 三論夏文化問題 [Three Discussions on the Question of Xia Culture]. Beijing: Zhonghua shuju, 1996.

Iijima Taketsugu 飯島武次. Ka-In bunka no kōkogaku kenkyū 夏殷文化の考古學研究 [Archeological Research into the Culture of the Xia and Yin Dynasties]. Tokyo: Yamakawa, 1985 .

Jin Jingfang 金景芳. Zhongguo nuli shehui shi 中國奴隸社會史 [A History of Slavery in China]. Shanghai: Shanghai renmin chubanshe, 1983.

Li Weiming 李維明. “Erlitou wenhua yi qi yicun yu Xia wenhua chushi 二里頭文化一期 遺存與夏文化初始 [Phase I of the Erlitou Culture and the Origins of Xia Culture].” Zhongyuan wenwu 中原文物, no. 1 (2002): 33-42.

Li Zhongci 李忠慈, ed. Zhongguo lishi renwu shuping: gudaishi bufen shang 中國歷史 人物述評: 古代史部分(上) [A Review on Chinese Historical Figures: Ancient History Volume, part 1)]. Tianjin: Tianjin shehui kexueyuan chubanshe, 1990.

Liu Qiyi 劉啟益. “Xizhou jinian tongqi yu Wuwang zhi Liwang de zaiwei nianshu 西 周紀年銅器與武王至厲王的在位年數 [Western Zhou Bronzeware Chronology and Reign Year Counts from King Wu to King Li].” Wenshi 文史, no. 13 (1982).

Liu Xu 劉緒. Xia-Shang-Zhou kaogu tanyan 夏商周考古探研 [Research into Xia, Shang and Zhou Dynasty Archeology]. Beijing: Kexue chubanshe, 2014.

Lv Zhenyu 呂振羽. Shiqianqi Zhongguo shehui yanjiu 史前期中國社會研究 [Research into Prehistoric Chinese Society]. Beijing: Renwen shudian, 1934.

Ma Chengyuan 馬承源. “Xizhou jinwen he lishi de yanjiu 西周金文和歷史的研究 [Research on the Bronze Inscriptions and History of the Western Zhou Dynasty]." Shanghai bowuguan jikan 上海博物館集刊 [Periodical of Shanghai Museum]. Shanghai: Shanghai guji chubanshe, 1982.

Meng Fanren 孟凡人. “Shitan Xia wenhua ji qi yu Shang wenhua de guanxi wenti 試 談夏文化及其與商文化的關係問題 [A Tentative Discussion on the Relationship between Xia Culture and Shang Culture]." Zhengzhou daxue xuebao (zhexue shehui kexue ban) 鄭州大學學報(哲學社會科學版), no. 1 (1979): 13-23.

Rong Mengyuan 榮孟源. “Shitan Xizhou jinian 試談西周紀年 [A Tentative Discussion on the Year Numbering System of the Western Zhou Dynasty]." Zhonghua wenshi luncong 中華文史論叢, no. 1 (1980): 1-21. 
Shinzo Shinjo 新城新藏. “Zhou chu zhi niandai 周初之年代 [A Chronology for the Early Zhou Period]." In Dongyang tianwenxueshi yanjiu 東洋天文學史研究 [Research into the History of East Asian Astronomy], trans. Shen Xuan 沈玷, 26-159. Shanghai: Zhonghua xueyishe, 1933 .

Tang Lan 唐蘭. “Zhongguo gudai lishi shang de niandai wenti 中國古代歷史上的年 代問題 [The Question of Chronology in Ancient Chinese History]." Xin jianshe 新建設, no. 3 (1955): 48-52.

Tian Changwu 田昌五. “Gushi de niandai wenti 古史的年代問題 [The Question of Chronology in Ancient History]." In Jinian Wang Yirong faxian jiaguwen yi bai nian lunwenji 紀念王懿榮發現甲骨文一百年論文集 [Collected Papers Commemorating the 10oth Anniversary of the Discovery of the Oracle Bones by Wang Yirong]. Jinan: Qilu shushe, 2000.

Tian Changwu 田昌五. “Xia wenhua tansuo 夏文化探索 [An Exploration of Xia Culture]." Wenwu 文物, no. 5 (1981): 18-26+58.

Wang Kelin 王克林. “Cong Longshan wenhua de jianzhu jishu tansuo Xia wenhua 從 龍山文化的建築技術探索夏文化 [Exploring the Xia Culture from the Construction Technology of the Longshan Culture]." Shanxi daxue xuebao (zhexue shehui kexue ban) 山西大學學報 (哲學社會科學版), no. 3 (1980): 75-78.

Wu Qichang 吳其昌. “Jinwen yinianbiao 金文疑年表 [A Table of Suspected Years in Chinese Bronze Inscriptions]." In Jinwen lishuo shuzheng, juan 6, 7 金文歷朔疏證 (卷六、卷七) [A Calendar Verification of Bronze Inscriptions, vols. 6, 7]. Shanghai: Shangwu yinshuguan, 1936.

Wu Ruzuo 吳汝祚. “Guanyu Xia wenhua ji qi laiyuan de chubu tansuo 關於夏文化及 其來源的初步探索 [A Tentative Exploration of Xia Culture and Its Origins].” Wenwu 文物, no. 9 (1978): 70-74.

Xia Nai 夏鼎. “Tantan tantao Xia wenhua de jige wenti 談談探討夏文化的幾個問題 [On Some Issues Related to Xia Culture]." Henan wenbo tongxun 河南文博通訊, no. 1 (1978): 32-33.

Xia-Shang-Zhou duandai gongcheng zhuanjia zu 夏商周斷代工程專家組. XiaShang-Zhou duandai gongcheng 1996-200o nian jieduan chengguo baogao jianben 夏商周斷代工程 1996-2000 年階段成果報告(簡本) [The Xia-Shang-Zhou Chronology Project Report for the years 1996-200o (abridged)]. Beijing: Shijie tushu chuban gongsi, 2000.

Xu Shunzhan 許順湛. “Xiadai wenhua de zai tansuo 夏代文化的再探索 [A ReExploration of Xia Culture].” Henan wenbo tongxun 河南文博通訊, no. 3 (1979):13-21. Xu Zhaofeng 徐昭峰 and Cao Rui 曹荵. “Kaoguxue yu Xia wenhua tansuo 考古學與夏 文化探索 [Exploring Archeology and Xia Culture].” In Xia Shang duyi yu wenhua,yi: Xia Shang duyi kaogu ji jinian yanshi shangcheng faxian 30 zhou nian guoji xueshu yantaohui lunwenji 夏商都邑與文化 $($ 一): 夏商都邑考古暨紀念偃師商城發現 30 
週年國際學術研討會論文集 [The Cities and Culture of the Xia and Shang Dynasties, vol. 1: Proceedings of the International Symposium on the Archeology of the Cities of the Xia and Shang Dynasties and the 3oth Anniversary of the Discovery of the Shangcheng Site in Yanshi], ed. Zhongguo shehui kexueyuan kaogu yanjiusuo 中國社會科學院 考古研究所, 89-97. Beijing: Zhongguo shehui kexue chubanshe, 2014.

Yin Weizhang 殷瑋璋. “Guanyu Xiadai wenhua de tansuo 關於夏代文化的探索 [On Exploring the Culture of the Xia Dynasty]." In Xin Zhongguo de kaogu faxian he yanjiu 新中國的考古發現和研究 [Archeological Discoveries and Research in New China], ed. Zhongguo shehui kexueyuan kaogu yanjiusuo 中國社會科學院考古研 究所, 211-15. Beijing: Wenwu chubanshe, 1984 .

Zhan Ziqing 詹子慶. Xiashi yu Xiadai wenming 夏史與夏代文明 [History of the Xia Dynasty and Its Civilization]. Shanghai: Shanghai kexue jishu wenxian chubanshe, 2007.

Zhang Guoshuo 張國碩. “Xia jinian yu Xia wenhua yicun chuyi 夏紀年與夏文化遺存 㑇議 [My View on the Chronology of the Xia Dynasty and the Xia Culture Site]." Zhongguo wenwu bao 中國文物報, no. 20 (2001): 7 .

Zhang Xuelian 張雪蓮 and Qiu Shihua 仇士華 et al. “Xinzhai Erlitou Erligang wenhua kaogu niandai xulie de jianli yu wanshan 新些一二里頭一二里岡文化考古年代 序列的建立與完善 [The Establishment and Improvement of the Xinzhai-ErlitouErligang Culture Chronology].” Kaogu 考古, no. 8 (2007): 74-89.

Zhang Zhongpei 張忠培. “Guanyu Erlitou wenhua he Xiadai kaoguxue yicun de ji dian renshi 關於二里頭文化和夏代考古學遺存的幾點認識 [Some Interpretations of Erlitou Culture and Archeological Remains of the Xia Dynasty]." Zhongguo lishi $w e n w u$ 中國歷史文物, no. 1 (2009): 4-8+2+93.

Zhao Zhiquan 趙芝荃 and Liu Zhongfu 劉忠伏. “Shitan Yanshi Shangcheng de shijian niandai bing jian lun Xia wenhua de shangxian 試談偃師商城的始建年代並兼論夏 文化的上限 [A Tentative Discussion on the Founding Year of Shangcheng, Yanshi, and the Upper Limit of Xia Culture].” In Huaxia wenming, diyiji 華夏文明(第一集) [Chinese Civilization, vol. 1], ed. Tian Changwu 田昌五, 180-196. Beijing: Peking University Press, 1987.

Zheng Xuan 鄭玄, annot., Kong Yingda 孔穎達, comm. “Liji zhengyi 禮記正義 [Interpretations of the Book of Rites].” In Shisanjing zhushu 十三經注疏 [Commentary on the Thirteen Classics], ed. Ruan Yuan 阮元, 1221-1696. Shanghai: Shanghai guji chubanshe, 1997 .

Zhongguo shehui kexueyuan kaogu yanjiusuo 中國社會科學院考古研究所, ed. Erlitou 二里頭 (1999-2006). Beijing: Wenwu chubanshe, 2014.

Zhongguo shehui kexueyuan kaogu yanjiusuo 中國社會科學院考古研究所, ed. Zhongguo kaoguxue Xia Shang juan 中國考古學.夏商卷 [Chinese Archeology: The Xia-Shang Volume]. Beijing: Zhongguo shehui kexue chubanshe, 2003. 
Zhongguo xian Qinshi xuehui 中國先秦史學會 and Luoyangshi dier wenwu gongzuodui 洛陽市第二文物工作隊, ed. Xiawenhua yanjiu lunji 夏文化研究論集 [Xia Culture Research: A Monograph Series]. Beijing: Zhonghua shuju, 1996.

Zhu Fenghan 朱鳳瀚 and Zhang Rongming 張榮明, ed. "Xizhou zhuhou wang niandai zhushuo yilanbiao 西周諸侯王年代諸說一覽表 [A Table of the Various Theories of the Chronology of the Kings and Lords of the Western Zhou Dynasty]." In Xizhou zhu wang niandai yanjiu 西周諸王年代研究 [Research into the Chronology of the Kings of the Western Zhou Dynasty], 432-433. Guiyang: Guizhou renmin chubanshe, 1998.

Zhu Shaohou 朱紹侯 et al., ed. Zhongguo gudaishi shang 中國古代史(上) [Ancient Chinese History, part 1]. Fuzhou: Fujian renmin chubanshe, 2006. 